\title{
TAKING LEGITIMACY SERIOUSLY: A RETURN TO DEONTOLOGY
}

\author{
Eric Heinze*
}

Democracy is the ongoing product of public discussion. ${ }^{1}$ With what legitimacy, then, can a democracy limit its citizens' participation in that discussion? The question has crystallised in recent years around problems of "extreme" expression, ${ }^{2}$ with a particular focus on so-called "hate speech." 3

Extreme expression plays a paradoxical role in a democracy. On the one hand, it involves a small fraction of all messages. Even democracies passionately combatting it tend to bring few prosecutions and to impose mild penalties. Stronger crackdowns generally target high-profile provocateurs like Jean-Marie

\footnotetext{
* Queen Mary, University of London (e.heinze@qmul.ac.uk). I would like to thank Antoon de Baets, Jill Hasday, Jim Weinstein, and Andreas Marcou for helpful comments provided on this essay, and Tom Boyle for his editorial assistance.

1. See, e.g., Ronald Dworkin, Foreword, in EXTREME SPEECH AND DEMOCRACY v-ix (Ivan Hare \& James Weinstein eds., 2009) [hereinafter EXTREME SPEECH]; JÜRGEN Habermas, MORAlbeWUbTSEIN UND KOMMUNIKATVES HANDElN [MORAL CONSCIOUSNESS AND COMMUNICATIVE ACTION] (1983) (Ger.); JÜRGEN HABERMAS, THEORIE DES KOMMUNIKATIVEN HANDELNS [THEORY OF COMMUNICATIVE ACTION] (1981) (Ger.); AlEXANDER MEIKLEJOHN, FREE SPEECH AND ITS RELATION TO SELFGOVERNMENT (1948); ROBERT C. POST, CONSTITUTIONAL DOMAINS (1995) [hereinafter Post (1995)]; Robert C. Post, Democracy and Equality, 603 ANNALS AMERICAN ACADEMy Pol. \& Legal TheOry 24 (2006) [hereinafter Post (2006)]; Robert C. Post, Equality and Autonomy in First Amendment Jurisprudence, 95 MICH. L. REV. 1517 (1997) [hereinafter Post (1997)]; Robert C. Post, Participatory Democracy and Free Speech, 97 VA. L. REV. 477 (2011) [hereinafter Post (2011a)]; Robert C. Post, Partipatory Democracy as a Theory of Free Speech: A Reply, 97 VA. L. REV. 617 (2011) [hereinafter Post (2011b)].

2. See Ivan Hare \& James Weinstein, General Introduction, in EXTREME SPEECH 4 (Ivan Hare \& James Weinstein eds., 2009); cf. ERIC HeInZE, HATE SPEECH AND DEMOCRATIC CITIZENSHIP 18-26 (2016) (examining legal concepts of extreme "speech" and "expression") [hereinafter HEINZE (2016)].
}

3. See infra notes 12,16 and 38 . 
LePen, ${ }^{4}$ Geert Wilders, ${ }^{5}$ or Dieudonné M'bala M'bala. ${ }^{6}$ The prosecuting states aim more for symbolic condemnation ${ }^{7}$ than for comprehensive enforcement, which tops few democracies' lists of priorities. On the other hand, for many writers, including Jeremy Waldron, extreme expression exemplifies a type of communication that can legitimately be excluded from public discourse, irrespective of its ranking within any broader scheme of human problems. Under well-drafted bans, Waldron maintains, speakers enjoy full freedom to state the substance of their views, but can rightly be asked to exercise care in the form of words they choose. $^{8}$

As I shall argue in this article, that form-substance distinction is what derails Waldron's approach. Defenders of speech bans cannot coherently divide acts of human expression into two parts - on the one hand, the substance of a message, conveying its viewpoint, and, on the other hand, that message's particular form of words, which might somehow be regulated without affecting the viewpoint. Like other defenders of bans, Waldron fails to establish his essential thesis, namely, that bans on extreme expression can be reconciled with democratic legitimacy. In his present debate with James Weinstein, it is Weinstein whoalthough I do note one caveat to Weinstein's view, for which I shall propose an amendment-fundamentally succeeds in depicting speech bans as democratically illegitimate. Fullyfledged democracies may take a host of measures to eliminate discrimination, but cannot legitimately penalise citizens who enter

4. See, e.g., Rachel Roberts, Jean-Marie Le Pen Charged over Alleged Antisemitic Remarks, INDEPENDENT (Feb. 13, 2017), http://www.independent.co.uk/news/world/jeanmarie-le-pen-charged-antisemitic-remarks-marine-le-pen-front-national-frenchpresidential-a7576151.html.

5. See, e.g., Netherlands Trial: Geert Wilders Guilty of Incitement, BBC (Dec. 9 2016), http://www.bbc.com/news/world-europe-38260377.

6. See, e.g., French Comedian Dieudonné Given Prison Sentence for Hate Speech, GUARDIAN (Nov. 25, 2016), https://www.theguardian.com/world/2015/nov/25/frenchcomedian-dieudonne-prison-sentence-hate-speech.

7. See, e.g., Christoph Seils, Selbstläufer symbolischer Politik: Wie ein Verbot der NPD auf die politische Agenda kam. in VERBOT DER NPD ODER MIT RECHTSRADIKALEN LEBEN? 44-50 (Claus Leggewie \& Horst Meier eds., 2002) (Ger.); Julie C. Suk, Denying Experience: Holocaust Denial and the Free-Speech Theory of State, in THE CONTENT AND ConteXt of HATE SPEeCH 144-63 (Michael Herz \& Peter Molnar eds., 2012). But see HEINZE, supra note 2, at 162-65.

8. See Jeremy Waldron, The Conditions of Legitimacy: A Response to James Weinstein, 32 CONST. COMMENT. 697, 700-01, 713-14 (2017). 
the public sphere to oppose pluralist values, however provocatively or crudely they may do so.

\section{THE DEMOCRATIC HURDLE}

Various elements can render speech "extreme." The blandest idea-a nursery rhyme or a toothpaste advertisement-can be broadcast at "extremely" high volume. Conversely, one can communicate "extremely" dangerous information in a whisper. From the outset, we must apply an age-old distinction in free speech jurisprudence between the extremity of a message and extremity in the manner of its expression. Today's fiercest debates about free speech emphasize the message. They focus not on extremities of "time, manner, or place," such as loud volumes late at night in residential areas. Jurists and scholars widely agree with at least minimal regulations for those elements. ${ }^{9}$

Nor do current controversies focus on objectionable content per se. Experts readily agree that content such as commercial fraud or courtroom perjury can be subjected to legitimate regulation. Rather, our intractable disputes concern the regulation of extreme messages on grounds of their viewpoint. ${ }^{10}$ In this article I shall use the phrase "bans on extreme expression per se" to denote laws imposing penalties on expression because of the viewpoint of the message, that is, because of its philosophy or worldview, and not because of excesses in the time, manner, or place of its communication.

Controversies about extreme expression have raged because they raise questions about how various principles ought to govern individual liberty. One, for example, is a consequentialist principle. History reveals atrocious political consequences fuelled by extreme speech acts. ${ }^{11}$ States, in the view of some observers,

9. See, e.g., Alexander Brown, Hate SpeEch Law: A Philosophical EXAMINATION 38-48 (2015); JOHN NOWAK \& RONALD ROTUNDA, CONSTITUTIONAL LAW 1447-74 (8th ed., 2009); EDWIN C. BAKER, HUMAN LIBERTY AND FREEDOM OF SPEECH 125-37, 162-63, 173-74 (1989).

10. Cf. HEINZE, supra note 2, at 19-22 (distinguishing between the concepts of "content" and "viewpoint"); James Weinstein, An Overview of American Free Speech Doctrine and Its Application in Hate Speech, in EXTREME SPEECH, supra note 1, at 82-83, $86-87$.

11. See, e.g., JOSEPH BEMBA, JUSTICE INTERNATIONALE ET LiBERTÉ D'EXPRESSION: LES MÉDIAS FACE AUX CRIMES INTERNATIONAUX (2008) (Fr.); MARTIN IMBLEAU, LA NÉGATION DU GÉNOCIDE NAZI, LIBERTÉ D'EXPRESSION OU CRIME RACISTE?: LE NÉGATIONNISME DE LA SHOAH EN DROIT INTERNATIONAL ET COMPARÉ 
must regulate such acts in order to safeguard not only vulnerable citizens, ${ }^{12}$ but the very survival of their democracies. ${ }^{13}$ The problem with consequentialist arguments is that causal links from extreme expression to mass atrocities have been established only in societies that are either undemocratic or very weakly democratic. Throughout decades of publications, any statistically demonstrable pattern of such causal links within fully-fledged democracies,${ }^{14}$ despite such expression being constantly present, have repeatedly been asserted yet have in no empirically reliable way been documented. ${ }^{15}$

Another principle is dignitarian: in the interest of ensuring basic civic equality for all citizens, government may legitimately penalise heinous expression found to be targeting the human dignity of others, particularly of members of socially vulnerable groups. On that view, tracing material causation from hateful expression to empirically demonstrable harms altogether misconstrues the types of harms such expression causes: the hateful expression is itself the harm. ${ }^{16}$

There are other such principles, reflecting liberal, republican, critical, and radical approaches. ${ }^{17}$ One in particular becomes decisive in the present debate between Weinstein and Waldron, namely, a democratic one. ${ }^{18}$ For Weinstein, along with writers like Ronald Dworkin and Robert Post, free speech ensures such an exceptionally high political value that even extreme expression

(2003) (Fr.); AleXANDER TSEsis, Destructive Messages: How Hate SpeEch PaVeS THE WAY FOR HARMFUL SOCIAL MOVEMENTS (2002).

12. See, e.g., Richard Delgado \& JeAn STEFANCIC, MuST We DEFEND NAZIS? (1999); Richard Delgado \& JeAn STEFAnCIC, Understanding Words THAT WOUND (2004); MARI J. MATSUdA ET AL., WORdS THAT WOUND: CRITICAL RACE THEORY, ASSAULTIVE SPEECH, AND THE FIRST AMENDMENT (1993).

13. See, e.g., WEHRHAFTE DEMOKRATIE: BEITRÄGE ÜBER DIE REGELUNGEN ZUM SCHUTZE DER FREIHEITLICHEN DEMOKRATISCHEN GRUNDORDNUNG (Markus Thiel ed., 2003) (Ger.).

14. See HeInze, supra note 2, at 69-78 (examining conditions under which democracies can be fully held to their legitimating criteria).

15. See id. at 125-29.

16. See, e.g., Steven J. Heyman, Free Speech and Human Dignity 164-83 (2008); Steven J. Heyman, Hate Speech, Public Discourse, and the First Amendment, in EXTREME SPEeCH, supra note 2, at 158-81; JEREMY WALDRON, THE HARM IN HATE SPEECH (2012); Cf. infra note 38.

17. See HEINZE, supra note 2, at 11-15.

18. See id. at 55-56, 88-94 (distinguishing between liberal and democratic theories). 
must be admitted ${ }^{19}$ into public discourse. ${ }^{20}$ Waldron agrees that democratic legislation, administration, and adjudication draw their legitimacy from the assumption of an open, public sphere in which all viewpoints may be aired. They disagree, however, about whether bans on extreme expression exclude speakers from that sphere in any way that diminishes a state's claim to democratic legitimacy.

Suppose certain citizens are to be excluded from public discourse pro tanto - that is, to the extent of their proscribed expression. The question for Weinstein and Waldron becomes: can the legal system legitimately be enforced against those citizens, insofar as they end up excluded from democratically essential processes of opinion formation? That question is crucial for all writers who defend bans on extreme expression per se on dignitarian grounds. Few of us, after all, can have any objection to the state using democratic processes to promote the basic value of human dignity through, for example, prohibitions on extrajudicial killings, torture, arbitrary detentions, rigged trials, or forms of racial or other discrimination. The problem arises when that value is deployed in apparent conflict with certain necessary foundations of a democracy. Dignitarians cannot legitimately proceed to speech bans except via democracy, whose demands of admitting all viewpoints must first be answered. Waldron's answer is that such bans need not exclude anyone from full democratic participation" ${ }^{21}$ : "it is misleading to say that hate speech restrictions prohibit the expression of certain views per se." ${ }^{22}$ In the remainder of the present essay I shall examine why that view fails.

19. Dworkin, supra note 1; Ronald Dworkin, Reply to Jeremy Waldron, in THE CONTENT AND CONTEXT OF HATE SPEECH: RETHINKING REGULATION AND RESPONSES 341-44 (Michael Herz \& Peter Molnar eds., 2012); Post (1995), supra note 1; Post (1997), supra note 1; Post (2006), supra note 1; Post (2011a), supra note 1; Post (2011b), supra note 1; James Weinstein, Hate Speech, Pornography, and the Radical Attack on Free Speech Doctrine (1999); James Weinstein, Hate Speech, Viewpoint Neutrality, and the American Concept of Democracy, in THE BOUNDARIES OF FREEDOM OF EXPRESSION \& ORDER IN AMERICAN DEMOCRACY 146, 161-66 (Thomas R. Hensley ed., 2001); James Weinstein, Participatory Democracy as the Central Value of American Free Speech Doctrine, 97 VA. L. REV. 491 (2011); James Weinstein, Participatory Democracy as the Basis of American Free Speech Doctrine: A Reply, 97 VA. L. REV. 633 (2011).

20. See HeINZE, supra note 2, at 26-30 (distinguishing public discourse from other spheres of expression).

21. See Waldron, supra note 8, at 703-04, 713-14.

22. Id. at 702 . 


\section{JUSTICE AND LEGITIMACY}

For Waldron, "the problem of legitimacy is to find a basis on which a law may permissibly be enforced even against people who disagree with its content." ${ }^{23} \mathrm{He}$ refers to that problem as "a function of its neglect in political theory." 24 Such a claim is puzzling, given that the pioneers of modern political theory seem concerned with little else.

Whilst deriving from legitimatus, meaning "to make lawful," it comes into usage only around the late 16th century. Writing in a precariously divided Europe, the aim of theorists like Hobbes, Montesquieu, or Rousseau is to develop legal frameworks that command obedience to substantive norms, notwithstanding disputes about those norms' substantive justice. To be sure, we often use the term "legitimacy" in looser, colloquial senses, to mean "rightness," "reasonableness," "fairness," or indeed "justice." Weinstein and Waldron, however, use it to denote some ethical reason for citizens to submit to a democratic legal system ("I obey as a matter of principle, because obeying the law of my democracy is the right thing to do") - that is, some reason to obey law beyond its sheer coercive power ("I obey solely as a matter of self-interest, to avoid fines, arrests, prison sentences, or a bad reputation").

Early modern theory is dominated by the contractarian model, a consensualist approach which revives in the 20th century under the liberal-democratic schema of John Rawls. A legal system, on the contractarian view, commands legitimacy when plausible grounds can be adduced to suggest that we implicitly consent in practice, or that we would explicitly consent in principle, to submit to that system. For example, we rarely give express consent to laws punishing homicides or larcenies; however, on a contractarian theory, our consent can reasonably be inferred inasmuch as (a) we ourselves desire those laws' protection; and (b) even if we do not desire such protection, or do not desire it in the particular form it takes within our legal system, democracy presupposes our freedom to voice any dissent from the prevailing law or to propose alternatives.

Plato had long ago penned the classic exposition of "speak or obey"-we are bound to obey law insofar as we had an

23. Id. at 707 (emphasis added)

24. Id. at 698 . 
opportunity to speak out in order to change it - in his dialogue Crito. Yet that dialogue is, in two senses, an oddity. First, in ancient Greek thought, Crito is an uncharacteristic example of legitimacy distinguished from substantive justice, a step that neither Plato nor Aristotle otherwise take in their political writings. Second, contrary to common readings of the dialogue enjoining absolute obedience to law, Crito by no means claims universality across all political systems. Its "speak or obey" mantra ${ }^{25}$ makes sense only for a regime, like that of ancient Athens, in which a prerogative of parrhēsia, of frank, unhindered, even dissident speech, enjoys quasi-absolute legal protection (at least for all fully-fledged male citizens), indeed as constitutive of the legal order. ${ }^{26}$

Plato's other major political writings, such as the Republic, Statesman, and Laws, remove that high status of free speech. Adopting a model polis geographically and demographically smaller and more homogeneous than the modern state, those other dialogues envisage a more strongly shared recognition of substantive justice among the citizens, ${ }^{27}$ thereby superseding any distinct question as to the legitimacy of procedures irrespective of substantive results. Aristotle, too, envisages a sufficient consensus on substantive justice to be in principle achievable, ${ }^{28}$ a consensus he deems adaptable to changing material or social circumstances. ${ }^{29}$ By contrast, with the rise of the early nationstate, spanning far larger and more diverse populations and land masses, the shift in focus from substantive justice to procedural legitimacy becomes decisive, starting in particular with Hobbes.

Hegel launches over a century of theorists rejecting contractarianism, from Marx to Heidegger, and others of all and sundry outlooks, all stridently rejecting the contractualist assumption of divorcing legal legitimacy from substantive

25. Crito 50a-e, in Plato: Complete Works 37, 44-45 (John M. Cooper ed., Hackett Pub. Co. 1997) [hereinafter Plato].

26. Cf. Eric Heinze, The Constitution of the Constitution: Democratic Legitimacy and Public Discourse, in RANCIÈRE AND THE PossibILITY OF LAW (Julen Extabe \& Mónica López Lerma eds., forthcoming 2017).

27. See, e.g., Republic 5.462a, in Plato, supra note 25, at 971, 1089; Laws 1.628a, in PLATO, supra note 25, at 1318,1322.

28. Aristotle, Politics 3.11.1281 ${ }^{\mathrm{a}} 42-81 \mathrm{~b} 6,82^{\mathrm{a}} 16-18$, in 2 THE COMPLETE WORKS OF ARISTOtLE: THE ReVised OXford TRANSLATION 1986, 2033 (Jonathan Barnes ed., Princeton Univ. Press 1984) (4th century B.C.E.) [hereinafter ARISTOTLE].

29. 2.8.1268 $33-69^{\mathrm{a}} 13$, in 2 ARISTOTLE, supra note 28 , at 1986, 2013-14. 
justice - thereby, in an important sense, returning to the postures of Plato and Aristotle. ${ }^{30}$ But we can leave those objections aside. Despite their disagreement, Waldron and Weinstein tacitly agree on a contractualist principle of legitimacy, disagreeing solely on the question of where that principle "leads." 31 For Weinsteinalthough this is not exactly his phrasing-a democracy that excludes citizens from democratic opinion formation pro tanto dissolves its social contract with them, relieving them of their duty to obey law. For Waldron, no such breach occurs: insofar as citizens remain free to express any viewpoint in substance, they remain fully subject law; in that respect, any such social contract remains in force.

Waldron's suggestion of neglect of the problem of legitimacy clearly does not apply, then, to Western political theory, which has long placed legitimacy-the principle of law "enforced even against people who disagree with its content"-at centre stage. Such theoretical neglect does, by contrast, characterize certain types of legal theory, notably of the old "how should judges decide cases" variety. We can certainly identify familiar strands of jurisprudence undertaken both by judges and by scholars "writing as" judges, who aim to interpret norms that they identify as already-established in law. That task of expounding the law's already-adopted norms either (a) assumes those norms' legitimacy within the legal system by definition, or (b) assumes legitimacy to be a false or irrelevant question. Both (a) and (b) are indeed attitudes that "neglect" questions of legal legitimacy. Genuine questions of legitimacy arise only when the rightness of already-admitted norms, or of otherwise prevailing interpretations of them, comes into question.

What, then, is legitimacy? Waldron's reference to law permissibly enforced against people who disagree with its content is adequate enough, subject to two reservations. First, I shall substitute his adverb "permissibly" with "rightly." After all, a magistrate could issue a warrant for a police squad to arrest a given citizen, knowing full well that the citizen has done nothing unlawful. When the police make the arrest, they do it "permissibly," because a warrant is by definition a permission. They do not, however, make the arrest rightly, even if

30. See, e.g., ERIC HEINZE, THE CONCEPT OF INJUSTICE $42-49$ (2013).

31. Waldron, supra note 8 , at 700. 
responsibility for the wrongful arrest lies entirely with the magistrate. Second, I shall substitute Waldron's noun "content" with the word "justice." After all, a dispute about a law's "content" can be entirely semantic. Individuals may agree on a law's aim, disputing only whether the "content" of a draft text, in the sense of its wording, is most conducive to achieving that aim as matter of sheer clarity, efficiency, strategy, or logistics. Those technical disputes are irrelevant to the problem of legitimacy. I shall postulate, then, that to be legitimate, a law must be rightly enforceable even against citizens who dispute its justice.

Two central questions of legitimacy arise in the present debate. The first is the question about the legitimacy of speech bans as such: can a democracy legitimately exclude extreme expression per se from public discourse? The second is the question about whether a democracy can rightly enforce other laws against persons who have been pro tanto excluded from democratic public discourse. The importance of the debate between Weinstein and Waldron is that it illustrates how that second question becomes decisive for resolving the first: if a democracy may not rightly enforce other laws against citizens excluded pro tanto from public discourse, then bans on extreme expression perforce become illegitimate. That is the question to which we now turn in Section 3, as it will depend on whether bans on extreme expression per se end up necessarily excluding viewpoints from public discourse.

\section{FORM AND SUBSTANCE}

For Waldron, citizens remain free to articulate the substance of any viewpoint, because an appropriately worded ban on extreme expression regulates only the form of that viewpoint's expression. ${ }^{32}$ In essence, say what you like, just tone down the language. Theorists of language, however, abandoned that formsubstance distinction ages ago. Its last exponents were the 20th century logical positivists, such as Rudolph Carnap ${ }^{33}$ and Alfred

32. See Waldron, supra note 8, at 700-01, 713-14.

33. Rudolf CARnap, Der logische Aufbau der Welt [The Logical STRUCTURE OF THE WORLD] 1928 (Hamburg, Felix Meiner Verlag 1999). 
Ayer. ${ }^{34}$ Logical positivism quickly became discredited, however, by the "linguistic turn" in philosophy and social sciences. ${ }^{35}$

Consider the sentence "Eve desires the apple." We can imagine any number of similar utterances: "Eve craves the apple," "The apple is tempting Eve," "The apple sings out to Eve," and so forth. On the logical-positivist view, those sentences share a core or fixed meaning, something like: "Eve wants the apple." Accordingly, if the state of Puritania bans the use of the verbs "desire," "crave," "tempt," and "sing," only the form of expression is lost, not the substance. The substance can be conveyed through the verb "want." After all, who ever heard of singing apples?

If I complain that "want," "desire," and "crave" are separated by nuance, that their differences are not objectively ascertained but rather a matter of "hunch" or "intuition," the logical positivists insist that such differences can only be either demonstrable or meaningless. ${ }^{36}$ They might add that what appear to be subjective differences are in fact matters of degree: the verb "desires" just means, for example, that Eve "really wants" the apple, and "craves" just means, to quote the Spice Girls, that Eve "really, really wants" it.

Given the scope of the present essay, I shall forego any attempt to summarise over a century of post-Wittgensteinian linguistic philosophy, post-Heideggerian phenomenology, postSaussaurian semiotics, post-Freudian social theory, and postromantic aesthetic theory. I'll simply assume that the differences between "want," "desire," and "crave," even when they at times correlate to differences of degree, do not wholly reduce to material or measurable quanta. Such words are never perfectly coextensive nor perfectly interchangeable. Barring ironic contexts, "Eve craves the apple" surely does mean that she wants it, and indeed that she desires it, but need not exhaustively and exclusively mean either.

Puritania, then, unquestionably bans certain types of expression on viewpoint-selective grounds. If I may lawfully say

34. Alfred Jules Ayer, Language, Truth and Logic (New York, Dover Pub. 1952) (1936).

35. See, e.g., ThE Linguistic TURn: EsSAYs In PhilosophicAl METHOD (Richard M. Rorty ed., Chicago, Univ. Chicago Press 1967).

36. AYER, supra note 34 . 
"Eve wants the apple" but not "Eve craves the apple," it is because "craves" sparks associations - ideas - that Puritania aims to repress, irrespective of the intelligence of the ban or of the links it presupposes between means and ends. Even the broadest hate speech ban in any fully-fledged democracy today does not, of course, sweep as broadly as Puritania's ban. Yet however prudently a ban on extreme expression per se may be tailored and implemented, it can never allow speakers to say "the same thing" but just with different words.

Waldron defends bans on "stirring up of hatred in a community against a section of or a group within that community." ${ }^{37}$ Before we proceed, and as a secondary though not unimportant matter, it may help to observe that Waldron apparently means not "community," but rather "state," in both instances in that sentence. The word "community" entails two meanings, either of which would serve more to dilute Waldron's thesis than to strengthen it. First, the term "community" is commonly used today to denote a sub-group within the modern state. Yet Waldron surely does not envisage laws drafted solely for the state to govern such groups internally. He presumably envisages the opposite: bans applicable to all citizens throughout the entirety of a given jurisdiction. Second, if Waldron is using "community" here in a universalist vein, to suggest the validity of his position even outside modern statist contexts-perhaps to include the societies of ancient Babylonians, or medieval Samurais, or pre-Columbian Aztecs - then he needs a theory of legal legitimacy applicable not only to modern democracies but to those societies as well. Given our present difficulties in agreeing even on modern, democratic legitimacy, it is hard to see how such an ambition can streamline his task. I shall therefore proceed on the assumption that Waldron's aim is to defend bans against stirring up of hatred within a modern state against a section of or a group within that state.

Now let's return to our main problem: any view that speech bans admit tidier versions of "the same" message, but which have no such "stirring up" intent or effect, suggests that we are dealing not with the same message, but with a different one, even if the two respective messages do both aim to promote the same broad (racist, homophobic, etc.) attitude. A given essage $M_{1}$ and a given

37. Waldron, supra note 8 , at $701 ; c f$. id. at 700-04. 
message $M_{2}$ may both be racist, and may both in that sense express some, perhaps similar racist viewpoint. Similarly, racist $R_{1}$ and racist $R_{2}$ may both be racists, and may both in that sense express some, perhaps similar racist viewpoint. Neither logically nor linguistically, however, does it follow either that $M_{1}$ and $M_{2}$, or that $R_{1}$ and $R_{2}$ express the same viewpoint.

Those who already feel put off by what they see as civillibertarians' perversely zealous defences of racist bullies and homophobic thugs may admittedly feel they can take little succour in my argument so far. For them, it's bad enough that opponents of hate speech bans have defended free speech for such low-lifes. Now, not even satisfied with that, by exploding formsubstance distinctions, I'm weirdly granting their Neanderthal outbursts (no offense to Neanderthals) a kind of expressive uniqueness. Now it seems that "faggot" and "filthy Jew" must be allowed to retain their special little bounce, their imaginative flair, which the more humdrum "homosexual" and "Jew" may not muster.

And yes, that's exactly what I'm saying, for the simple reason that the contrary view lacks any plausible theory of language. I wholly acknowledge that, as a purely practical matter, nominal replacements of vicious for anodyne turns of phrase can indeed be made. Such sterilising substitutions are certainly feasible as a matter of makeshift routine. What remains wholly false is any suggestion that the state thereby succeeds in regulating only a message's form and not its substance or viewpoint. To suggest the contrary is like saying: "Don't bother reading Finnegan's Wake. I'll explain its substance to you." Of course that comparison exaggerates the problem. Joyce's narrative patently amounts to something denser than the mindless word "faggot." But it is an exaggeration only in degree, not in character.

One objection to my view might be that some hateful utterances are fundamentally "performative." They operate not simply to express an idea, but above all to effectuate the realworld construction of others as detestable. That view has won wide acceptance, ${ }^{38}$ but it reads too literally the theory of linguistic

38. See, e.g., Rae Langton, Speech Acts and Unspeakable Acts, 22 PHIL. \& PUB. AFF. 293, 305-30 (1993); Rae Langton, Beyond Belief: Pragmatics in Hate Speech and Pornography, in SPEECH \& HARM: CONTROVERSIES OVER FREE SPEECH 72 (Ishani Maitra \& Mary Kate McGowan eds., Oxford, Oxford Univ. Press 2012); Ishani Maitra, Subordinating Speech, in SPEECH \& HARM: CONTROVERSIES OVER FreE SPEECH 94; 
performatives. To observe the "illocutionary" or "perlocutionary" effects of certain utterances is one thing. To suggest that, being performative, such effects thereby remove from those utterances any expression of a viewpoint is altogether another. If they did, how would we even know the utterances to be hateful? None of the writers examining the linguistic performativity of hate speech have ventured quite that far. ${ }^{39}$

\section{ILLEGITIMACY WITHOUT DISOBEDIENCE}

Waldron's form-substance distinction serves a broader strategy. He aims to establish that civil libertarians overstate the extent to which bans on extreme speech per se end up excluding citizens from public discourse. Waldron accuses them of making claims that are "as loose as they think they can get away with." ${ }^{40}$ He charges them with two types of "hyperbole." 41 First, Dworkin claims far too broadly that speakers as individuals end up altogether excluded from public discourse when they are penalised for their views. Second, Weinstein, albeit "more modest," ${ }^{42}$ still claims rather too broadly that not speakers as such but still their particular viewpoints end up illegitimately excluded.

Yet Waldron cannot sustain even that latter gripe, as it relies on the form-substance distinction. Consider an analogy. When U.S. public interest lawyers litigate against practices of racial gerrymandering, they commonly complain that black people end up "disenfranchised." That is a broad term, encompassing not only a range of possible material effects but also a-perfectly reasonable-rhetorical plea. Those lawyers do not claim that their clients have literally lost all rights of citizenship. Nor, then do they draw any conclusion that, until such time as the electoral boundaries be re-drawn, their clients must be deemed exempt from all duties of citizenship as well, gaining thereby the license to act with total lawlessness. Read in the context of his lifetime's output, none of which advocates radical disobedience to law,

Ishani Maitra \& Mary Kate McGowan, Introduction and Overview, in SPEECH \& HARM: Controversies over Free Speech 1. Cf. Judith Butler, Excitable Speech: A POLITICS OF THE PERFORMATIVE (1997).

39. For a further critique of performativity theories see HEINZE (2016), supra note 2, at $137-42$.

40. Waldron, supra note 8 , at 700 .

41. Id. at 701,711 .

42. Id. at 705 . 
Dworkin's "hyperbole" is arguably little different - or at any rate can plausibly be read in such terms.

Strictly speaking, however, Waldron does persuasively reject any right of disobedience that might be claimed by a citizen whose views are excluded under a ban on extreme speech per se. Weinstein, on Waldron's view, "wants to reach a point at which we can say that [some person] $\mathrm{P}$ has a right to disobey" a law contrary to P's banned viewpoint "or a right that it not be enforced against him." 43 This would indeed be my only serious reservation about Dworkin's or Weinstein's stances. In an effort to explain the democratic illegitimacy of viewpoint-selective penalties, Weinstein risks derailing his thesis by re-igniting wellworn disputes about justified disobedience to law. Dworkin or Weinstein certainly would be wrong to conclude that any such remedy follows from the illegitimacy of bans. Recall that theories of civil disobedience, as opposed to theories of anarchic opposition to all law, aim mostly to identify circumstances that render conduct ethically right despite entailing legal violations. Even the most indulgent theories generally prescribe that the dissenter must still face the legal consequences. ${ }^{44}$

One might try to retain a narrower immunity to law by limiting justified disobedience to laws "directly" relating to the proscribed speech, such as laws imposing upon employers various non-discrimination norms contrary to the viewpoints of excluded hate speakers. ${ }^{45}$ Ultimately, however, any such narrowing becomes too arbitrary. For example, a hate speaker expounding a comprehensively conspiratorial worldview (e.g., "Jews run the world") can link that outlook to any legal norm or practice, right down to a speed limit or a tax on cigarettes. Once a citizen is excluded pro tanto from public discourse, there is no area of law to which that exclusion becomes irrelevant in principle. Waldron wins, then, in rejecting any justified disobedience on the part of pro tanto excluded citizens. But that victory is secondary, not decisive. Dworkin and Weinstein remain entirely correct on the main point, that is, in deeming democratically illegitimate any ban on extreme expression per se. The only remedy either of them

43. Id. at 709 .

44. See, e.g., M. B. E. Smith, The Duty to Obey the Law, in A COMPANION TO THE Philosophy of LAW AND Legal TheORY 457, 465-74 (Dennis Patterson ed., Blackwell Pub. 1996).

45. Waldron, supra note 8, at 706 . 
needs to propose is that, to the extent of such bans' illegitimacy, they ought to be repealed.

The citizen's prerogative of expression within public discourse remains necessary to democracy, not as a matter of sheer expedience on a consequentialist criterion, but as a matter of principle - on a deontological criterion. To call an abridgment "slight" or de minimis is to misconstrue the character of a deontological argument. To draw a related analogy, in most democracies today the empirically measurable effect of one fraudulent ballot paper on an electoral outcome will usually be nil. On any consequentialist measure, it would have no impact and would be of no material importance, particularly in comparison to the many pressing problems states must every day confront.

But that purely consequentialist criterion diminishes the inherent illegitimacy of the falsified ballot paper to near-triviality. A deontological criterion yields precisely the opposite normativity. The illegitimacy of one single act of falsification is categorical. It is not materially negated even by purely negligible real-world effects. If such conduct is indeed rare overall, one might fairly be accused of exaggerating its significance as a practical matter, because the society may face more immanently threatening problems. So, yes, in a context of such rare voter fraud, I would surely overlook it and would focus instead on environmental protection or tax equity. But the absolute illegitimacy of even a single ballot falsification remains undiminished by the mere observation that the actual occurrence of such conduct is rare or of scant impact. Infrequency renders such wrongdoing less threatening in practice, not less infirm in principle. (We could draw many such analogies. If only one adult on the entire planet abused a child, then the evil of child abuse certainly would not create a general social problem, but that single adult's conduct would remain categorically heinous, wholly irrespective of the absence of such conduct by other adults.) You are certainly free to accuse me of hyperbole for insisting on the absolute illegitimacy of one fraudulent ballot paper, given such calamities as rampant war crimes or global warming. But all you are then making is a straightforward consequentialist observation about practical effects, and not a normative argument about legitimacy. 


\section{CRITERIA OF LEGITIMACY}

A problem with Waldron's claims about legitimacy in his writing prior to the present debate is that he had never in the past explained what he thinks the right concept of legitimacy to be, instead attempting only to explain why Dworkin's and Weinstein's are wrong. Waldron certainly proffers various arguments of general social policy to support bans on extreme speech, all of which only beg the question of those bans' legal legitimacy. That is why he and other defenders of bans need to win the present debate. If they lose, then all their remaining arguments, explaining that some extreme expression is $b a d,{ }^{46}$ fail to establish that a democracy can legitimately ban it. Having made the two adjustments proposed in Section 2, we did glean from Waldron's present article that to be legitimate, a law must be rightly enforceable even against citizens who dispute its justice. But that criterion is purely formal. It merely begs the question as to the kind of law that counts as "rightly enforceable."

It might help if, in addition to challenging Dworkin's or Weinstein's view in a solely offensive posture, he could propose precise criteria of his own. By an "offensive posture," I mean that Waldron aims only to explain why hate speech bans aren't illegitimate.$^{47} \mathrm{He}$ argues, for example, "what I have said doesn't deny that hate speech laws may have an impact on legitimacy; what I am denying is that they have an impact on the state's right to enforce particular laws against individuals." 48 That view presents a few puzzles, some easier to resolve than others.

Let's start with a preliminary obstacle, simply because of the conceptual precision our topic demands. To be sure, such a "right" is often ascribed colloquially to states, particularly in broadly ethical as opposed to strictly legal contexts. Yet strictly speaking-say, in a Hohfeldian sense-what Waldron surely means in characterising a state's scope of action in this area is not

46. See, e.g., Jeremy Waldron, The HARm In HATE SPEech 4, 30, 31, 33, 37, 39 , 45, 59, 65-69, 72, 96-97, 116-17 (2012) [hereinafter WALDRON (2012)]; Jeremy Waldron, Hate Speech and Political Legitimacy, in THE CONTENT AND CONTEXT OF HATE SPEECH 329, 331. Cf. Eric Heinze, Hate Speech and the Normative Foundations of Regulation, 9 INT'L J. L. CONTEXT 590, 614 (2013) [hereinafter Heinze (2013)]. See also works cited in note 12 , supra.

47. Waldron might be said to touch on legitimacy in his recourse to Rawls's construct of the well-ordered society, but does not do so in any obvious way. See critically Heinze (2013), supra note 46, at 606-14.

48. Waldron, supra note 8 , at 711 (emphasis added). 
its right to avail itself of existing law (which would merely beg the question at issue, namely, as to what that existing law may legitimately be), but rather its legitimate power both to make and to enforce "particular laws against individuals." 49 When we enquire into the extent of free speech, our enquiry is ordinarily into the extent of the individual's right to enjoy that freedom, as against a government's legitimate power to limit it.

What counts, then, as a legitimate power? As I have thus far argued, the illegitimacy of a ban on extreme expression per se does not invalidate a state's legitimate power to enforce other laws, such as non-discrimination laws, against persons who had been barred pro tanto from publicly speaking about those laws. What Waldron offers here, however, is a non-denial that bans may impact legitimacy. Is that a yes or a no? Given his repeated defence of bans, what is he claiming here? He cannot be referring to poorly drafted bans, since it is trivially obvious that a poorly drafted limit on essential democratic freedoms by definition impacts on legitimacy. What he apparently means is that even soundly drafted bans "may have an impact on legitimacy."

But how? Waldron commonly introduces his position on free speech not as a "wish to persuade" his audiences of hate speech bans" "wisdom and legitimacy," but only as a hope that his readers should better "understand" the bans' rationales. ${ }^{50}$ But those disclaimers are misleading. I shall leave aside the question of whether Waldron's many substantive claims can only seriously be construed as deeming bans to be necessary to achieve substantive justice. What lies beyond dispute is that, in his several writings, Waldron zealously insists that bans are permissible under criteria of democratic legitimacy. ${ }^{51}$ Yet here he claims that well-drafted bans "may" nevertheless be illegitimate. Bans can, then, be substantively just yet democratically flawed-so to speak, illegitimately good. But that approach turns legitimacy on its head. Waldron's task, on his own stated criterion, is to identify legitimate norms regardless of their substantive justice, and not substantive justice regardless of its legitimacy.

49. Id. at 711

50. See, e.g., WALDRON (2012), supra note 46, at 10; $c f$. id. at 11-12; Jeremy Waldron \& James Weinstein, The Legal Response to Hate Speech: Should the U.S. be more like Europe? 48:04 - 48:59 (Oct 26, 2012), http://online.law.asu.edu/Events/2012/HateSpeach (Retrieved Sep. 1, 2013).

51. See HeInZE (2016), supra note 3, at 25 n.79. 
In his previous writing Waldron observes - without express disapproval or proposing any alternative-that, "[i]n social science, legitimacy often means little more than popular support." ${ }^{2}$ In a nutshell, if Americans don't want bans, that's legitimate for them; but if Europeans do want bans, that's just as legitimate. Bans or no bans are equally legitimate- a view consonant with his questionable "I'm not taking a stand either way" protestations. That straightforwardly sociological or majoritarian criterion-legitimacy means whatever enough people want it to mean-would have spared everyone from Socrates to Kant much toil, as it equally turns legitimacy on its head. To collapse legitimacy into the sheer "is" of the head count is to empty it of any distinct meaning. Either legitimacy is an "ought" concept or it has no particular meaning at all. Waldron's job is not to collapse legitimacy into popular support, but, to the contrary, to ask whether or under what circumstances popular support, or any other criterion, supplies legitimacy.

In a break from those previous stances, however, Waldron does in the present exchange acknowledge a more distinctly normative criterion of legitiamcy. He claims to discover it in the views of "moral philosophers," for whom "the best argument for the legitimacy of our laws (or of any particular law L) is a showing that the laws are morally justified or that L in particular is morally justified." ${ }^{53}$ We have to take that thesis at face value because Waldron doesn't tell us who those moral philosophers are or how they defend that position against what any number of their fellow philosophers would have to recognise as its patent vacuousness. After all, since when is "morally justified" facially more perspicuous than "legitimate"? Theories of morals have been written for centuries. Which one are we assuming? Does this formula merely revert back to Waldron's earlier sociological or majoritarian criteria?

On face value it is far from clear, moreover, that such a test is a distinct criterion of legitimacy at all, as opposed to a criterion that merely confuses legitimacy with its aforementioned colloquial meanings, ${ }^{54}$ indifferently equating it with policy or justice or goodness or morals or ethics writ large. Nowhere, for

52. WALDRON (2012), supra note 46, at 184. Cf. HeINZE (2016), supra note 2, at 44.

53. Waldron, supra note 8, at 707 .

54. See above Section 2. 
example, does Waldron distinguish legitimacy in that formula from its more particular meaning within the contractarian tradition, which at least prima facie it rather blatantly contradicts. Unfortunately, then, Waldron does propose here a notion of legitimacy, but it in no way progresses beyond his earlier sociological or majoritarian criterion - which is not a normative criterion at all, but merely a social barometer.

\section{DEMOCRACY AND SECURITY}

In a curious coda, Waldron concludes his essay on a completely novel point. He had, again, regularly invoked the form-content distinction, which was only ever relevant to try (unsuccessfully, as I have claimed) to argue that the state is not punishing the expression of particular viewpoints. Now, as if making an obvious afterthought, he abruptly suggests that it doesn't matter even if bans do target certain viewpoints. Now suddenly viewpoints altogether ought to be censored insofar as "a society needs social peace and it is entitled to the assistance of citizens in maintaining that peace." 55

No democrat even fleetingly versed in the history of free speech can mean such a claim with anything like the baldness with which Waldron states it. Our long chronicle of censorship, dating back centuries and indeed millennia, is nothing but a history of claims - often made in good faith-about "social peace": from imprisoning heretics, to censoring liberals, to banning communists, to hunting down jihadists. It's largely the origin of modern First Amendment jurisprudence in the U.S. As far back as Plato's Republic, proceeding via Hobbes's Leviathan, all sorts of individual freedoms have been deemed abridgeable in the name of achieving "social peace."

Waldron concedes that in difficult cases the law should generally stay "on the liberal side." ${ }^{56}$ Yet with his core concepts of legitimacy so wholly indeterminate, he offers no obvious point at which claims for "social peace" end and those for "the liberal side" begin. What's to stop Waldron's concept of "social peace" reducing to straightforwardly majoritarian or sociological criteria just as readily as his concept of legitimacy?

55. Waldron, supra note 8 , at 713 .

56. WALDRON (2012), supra note 46, at 126. 
Once again, Waldron appears to make a claim about legitimacy, but ends up altogether side-lining it as a distinct political value, this time summarily collapsing it into the consequentialist terms of the weary "freedom versus security" trade-off. Even on that point, Waldron is simply assuming a material causation - that such abridgment of freedom does indeed lead to greater social peace-for which he cites no evidence. ${ }^{57} \mathrm{He}$ frequently praises various democracies for their bans, but for all of his consequentialist assumptions he never actually examines empirical evidence from any of them in any rigorous way. On the available record, "social peace" has declined over several decades in a number of democracies that maintain bans, ${ }^{58}$ some of them applauded by Waldron.

And if Waldron did have such evidence? Social peace is an interest of all governments. Yes, a democracy needs it, but only in the sense that any constitutional form needs it. It is in no way an interest specifically constitutive of democracy. Jill Hasday altogether reasonably suggests that democracies may "need social peace more than authoritarian regimes because they depend more on the population's cooperation, as opposed to fear." ${ }^{59}$ Whether states rely on sticks or carrots, however, is a question about means, not ends. Authoritarian states indeed seek peace through intimidation, whilst democracies seek it through trust. In both cases, however, it is social peace they seek. Social peace is, in sum, a security interest shared by all states, and not an interest unique to democracies. Once again, then, we witness the question of democratic legitimacy not resolved but eschewed. Serving a security interest may well legitimate a state as a state but in no way legitimates it as a democracy. For the time being, then, Waldron remains at square one. Any specifically democratic concept legitimacy is inherently normative. If one wishes to defend bans on extreme expression per se, then one must adduce a specifically normative theory of legitimacy - and it must be a democratic one. Waldron and other defenders of speech bans have thus far failed at that task.

57. HEINZE (2016), supra note 2, at 124-29.

58. See, e.g., id. at 145-53.

59. Private communication of 5 March 2017, on file with author. 